\title{
The Inability of Mosquitoes to Transmit Aids Validates the Germ Terrain Duality Theory, Tackling the Corona Virus with Electricity
}

\author{
Mister Seun Ayoade* \\ Independent Researcher Alumnus, College of Medicine University of Ibadan, Oyo State, Nigeria \\ *Corresponding author: Mister Seun Ayoade, Independent Researcher Alumnus, College of Medicine University of \\ Ibadan, Oyo State, Nigeria
}

\begin{tabular}{|c|c|}
\hline ARTICLE INFO & ABSTRACT \\
\hline Received: 㗀 July 01, 2020 & \multirow{2}{*}{$\begin{array}{l}\text { Citation: Mister Seun Ayoade. The Inability of Mosquitoes to Transmit Aids Validates } \\
\text { the Germ Terrain Duality Theory, Tackling the Corona Virus with Electricity. Biomed J } \\
\text { Sci \& Tech Res 28(5)-2020. BJSTR. MS.ID.004707. }\end{array}$} \\
\hline Published: 蔧 July 10, 2020 & \\
\hline
\end{tabular}

\section{Opinion}

Laymen have often asked if mosquitoes could bite an AIDS patient and then transmit AIDS to a healthy person by sucking his or her blood-the way malaria, zika, dengue and encephalitis are spread. Luckily for us all, mosquitoes can't spread AIDS because:

1. Mosquito cells don't have the T cell antigen, so the AIDS can't multiply or duplicate in the mosquito

2. The AIDS virus cannot thrive in mosquito saliva. Plus AIDS can't be spread by saliva. AIDS is spread via blood, rectal fluids, breast milk and reproductive fluids instead.

3. HIV (human immunodeficiency virus) is digested in mosquitoes [1-3].

The Germ-Terrain duality theory of disease states that the etiology of certain diseases/diseased states is better explained as a complex interplay between germs and the inherent anatomical/ physiological integrity of the body cells. It argues that the etiology of certain diseases is not fully explained merely by the presence of germs (Germ Theory) or by a mere loss of cellular integrity (Terrain Theory). As a result the prevention and treatment of such diseases should focus not just on fighting germs but on maintaining/ restoring the anatomical/physiological cellular integrity. The Germ-Terrain duality theory is a harmonization of the current Germ Theory (popularized by Louis Pasteur) and the hitherto discarded Terrain Theory (popularized by Pierre Bechamp) [4-6].
The above parameters that prevent mosquitoes from being infected by or transmitting HIV are terrain related. If terrain had nothing to do with etiology mosquitoes would be susceptible to and transmit AIDS- a frightful scenario indeed! The failure of the human immune deficiency virus to afflict and be transmitted by the mosquito (culicidae) validated the germ terrain duality theory. In closing, I wish to suggest that scientists consider electricity as a deterrent in tackling the pesky corona virus. As it has been demonstrated that electricity can disable viruses [7] and that viruses can be made to generate electricity [8] this frontier should be examined.

\section{References}

1. Kloft WJ (1989) Is there the possibility of transmission of AIDS by bloodsucking insects Naturwissenschaften 76(4): 149-155.

2. Marx PA, Apetrei C, Drucker E (2004) AIDS as a zoonosis? Confusion over the origin of the virus and the origin of the epidemics. J Med Primatol 33(5-6): 220-226

3. Bockarie MJ, Paru R (1996) Can mosquitoes transmit AIDS? PNG Med J 39(3): 205-207.

4. Ayoade S (2017) Etiology, Epidemiology and Therapeutic History of Malaria Validate Germ-Terrain Duality Postulates Thereof. J Mol Genet Med 11: 261.

5. Mister SA (2017) Antimalarials Validate the Germ Terrain Duality Theory. JOJ Nurse Health Care 2(5): 555600.

6. Mister Seun Ayoade (2017) The Differences Between the Germ Theory, the Terrain Theory and the Germ Terrrain Duality Theory. JOJ Nurse Health Care 4(2): 555631. 
7. Etsuko Kumagai, Masato Tominaga, Shouichiro Nagaishi, Shinji Harada (2007) Effect of Electrical Stimulation on Human Immunodeficiency Virus type-1 Infectivity Appl Microbiol Biotechnol 77(4): 947-953.

ISSN: $2574-1241$

DOI: $10.26717 /$ BJSTR.2020.28.004707

Mister Seun Ayoade. Biomed J Sci \& Tech Res

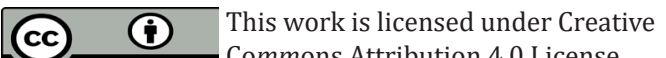
Commons Attribution 4.0 License

Submission Link: https://biomedres.us/submit-manuscript.php
8. (2012) Berkeley Lab Scientists Generate Electricity from Viruses. New approach is a promising first step toward the development of tiny devices that harvest electrical energy from everyday tasks. News Release Dan Krotz 510: 486.

$\begin{array}{ll}\text { BIOMEDICAL } & \text { Assets of Publishing with us } \\ \text { RESEARCHES } & \text { - Global archiving of articles } \\ & \text { - Immediate, unrestricted online access } \\ & \text { - Rigorous Peer Review Process } \\ & \end{array}$

